\title{
Population biology of spine shrimp Exhippolysmata oplophoroides (Holthuis) (Caridea, Hippolytidae) in a subtropical region, São Paulo, Brazil
}

\author{
Vivian Fransozo ${ }^{1}$, Rogério C. Costa ${ }^{2}$, Giovana Bertini ${ }^{3} \&$ Valter J. Cobo ${ }^{4}$ \\ ${ }^{1}$ Corresponding author. Departamento de Zoologia, Instituto de Biociências, Universidade Estadual Paulista. \\ Caixa Postal 510, 18618-000 Botucatu, São Paulo, Brasil. E-mail: vibiologa@yahoo.com.br \\ 2 Faculdade de Ciências, Universidade Estadual Paulista. 17033-360, Bauru, São Paulo, Brasil. \\ E-mail: rccosta@fc.unesp.br \\ ${ }^{3}$ Universidade Estadual Paulista, Unidade de Registro. 11900-000 Registro, São Paulo, Brasil. \\ E-mail: gibertini@registro.unesp.br \\ ${ }^{4}$ Departamento de Biologia, Universidade de Taubaté. 12020-270 Taubaté, São Paulo, Brasil. E-mail: vjcobo@uol.com.br
}

\begin{abstract}
The population biology of Exhippolysmata oplophoroides (Holthuis, 1948) was studied in Ubatuba Bay

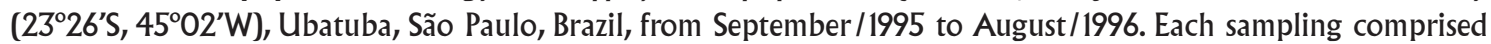
eight transects (14000 $\mathrm{m}^{2}$ each), sampled monthly with three repetitions. The specimens were classified with respect to the presence or absence of eggs in the abdominal appendages. Spine-shrimps occurred only on six transects, being most abundant on transect II, with the highest incidence in late spring and throughout the summer months. Ovigerous and non-ovigerous shrimps were present year-round, in an approximately similar proportion (1:1). Site II in Ubatuba Bay is characterized by high salinity and oxygen values, temperature between 26 and $29^{\circ} \mathrm{C}$, low organic matter content in the sediment, and a bottom composed of very fine sand; these environment and biological features allow the establishment and maintenance of the population of $E$. oplophoroides. KEY WORDS. Distribution, population structure, reproduction, Southeastern Brazil, spine shrimp.
\end{abstract}

RESUMO. Biologia populacional do camarão espinho Exhippolysmata oplophoroides (Holthuis) (Caridea, Hippolytidae) numa região subtropical, São Paulo, Brasil. A biologia populacional de Exhippolysmata oplophoroides

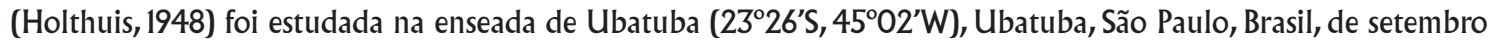
de 1995 até agosto de 1996. Cada amostragem compreendeu oito transectos (14000 $\mathrm{m}^{2}$ cada), amostrados mensalmente com três repetições. Os espécimes foram classificados quanto à presença ou ausência de ovos nos apêndices abdominais. Os camarões espinhos ocorreram somente em seis transectos, sendo mais abundantes no transecto II, com a maior incidência no final da primavera e ao longo dos meses de verão. Indivíduos ovígeros e não ovígeros estiveram presentes o ano todo, numa proporção semelhante a 1:1. O transecto II é caracterizado por altos valores de salinidade e oxigênio, temperatura entre 26 e $29^{\circ} \mathrm{C}$, baixo teor de matéria orgânica e sedimento composto por areia muito fina. Tais características biológicas e ambientais permitem o estabelecimento e a manutenção da população de E. oplophoroides na região de estudo.

PALAVRAS CHAVE. Camarão espinho, distribuição, estrutura da população, sudeste do Brasil, reprodução.

Among many caridean shrimp species occurring along the coast of São Paulo, the spine-shrimp Exhippolysmata oplophoroides (Holthuis, 1948) is the most abundant. It is a very common caridean in shallow marine waters along the southeastern coast of Brazil. Its common name in North America is "redleg humpback shrimp," whereas in Brazil it is known as the "camarãoespinho" or "spine-shrimp;" we use the latter name herein. As noted by Costa et al. (2000), the spine-shrimp is usually found together with the commercially exploited penaeid shrimps
Farfantepenaeus paulensis (Pérez-Farfante, 1967), F. brasiliensis (Latreille, 1817), Litopenaeus schmitti (Burkenroad, 1936) and Xiphopenaeus kroyeri (Heller, 1862), and is consumed by the local people. Despite its common occurrence in these fisheries, the biology of the spine-shrimp is poorly known. CHAcur \& Negreiros-Fransozo (1999) reported that it reproduces continuously in the Ubatuba region. In that population, CHACUR \& Negreiros-Fransozo (1999) found no specimen with mature male morphological features, which suggests that sexual reversion 
occurs in this species; sexual reversion is very common in marine caridean shrimps (Kagwade 1981, Bauer 1986, Fiedler 1998, Bauer \& Holt 1998). Negreiros-Fransozo et al. (2002) described the first larval stage of the spine-shrimp from ovigerous females, also obtained in the Ubatuba region.

In biological studies on benthic organisms, the environmental factors usually monitored are temperature, salinity, dissolved oxygen, texture of the sediment and organic matter. Taken together, these features can characterize peculiar environmental situations which can provide favorable conditions for the development of certain species (BUCHANAN \& STONER 1988, González-Gurriarán et al. 1993, Bertini \& Fransozo 1999, Costa \& Fransozo 2004a, Costa et al. 2004, 2005a, b).

The aim of this study is to analyze the population biology of E. oplophoroides in Ubatuba Bay, Ubatuba, São Paulo, Brazil, with emphasis on spatial and seasonal aspects. The environmental factors influencing its ecological distribution were also examined.

\section{MATERIAL AND METHODS}

Ubatuba Bay $\left(27^{\circ} 26^{\prime} \mathrm{S}, 45^{\circ} 02^{\prime} \mathrm{W}\right)$ (Fig. 1) is located adjacent to the Municipality of Ubatuba on the northern coast of São Paulo. The area includes five sandy beaches delimited by rocky shores. The total area of the bay is about $8 \mathrm{~km}^{2}$; its width is about $4.5 \mathrm{~km}$ at the entrance and decreases landward. Four small rivers (Indaiá, Grande, Lagoa and Acaraú) flow into this bay. Fresh water also enters from the Atlantic forest and the surrounding mangroves, reducing the salinity in the shallow water in the bay. Mantelatto \& Fransozo (1999) provided a detailed characterization of the physical and chemical parameters in Ubatuba Bay, during the same period as this study (Tabs I and II).

Shrimps were sampled monthly from September, 1995 to August, 1996 in Ubatuba Bay, from a fishing boat equipped with two double-rig nets (mouth $3.5 \mathrm{~m}$ wide, mesh size $15 \mathrm{~mm}$ in the body and $10 \mathrm{~mm}$ in the cod end). Each sample series comprised 8 transects $\left(14,000 \mathrm{~m}^{2}\right.$ each), each transect sampled repeatedly on three consecutive days. The specimens obtained were sorted and stored in $70 \%$ ethanol. It was not possible to sex the specimens by macroscopic procedures, because ovigerous shrimps have the same external morphological features as non-ovigerous ones. Therefore the specimens were classified based on the presence or absence of eggs in the abdominal appendages.

All the specimens captured in each transect were counted. When a large number of individuals were caught on a particular transect, subsamples of spine-shrimps were taken following WENNER et al. (1991): if $=50<\mathrm{n}<250$ individuals were collected, then a minimum of 50 randomly selected specimens were measured; if $>250<\mathrm{n}<500$ individuals were caught, then a minimum of $20 \%$ were measured; and when $n>500$ were caught, a minimum of $10 \%$ were measured.

The carapace length (CL), defined as the distance from the orbital angle to the posterior margin of the carapace, was measured to the nearest $0.1 \mathrm{~mm}$ for all the individuals sorted.
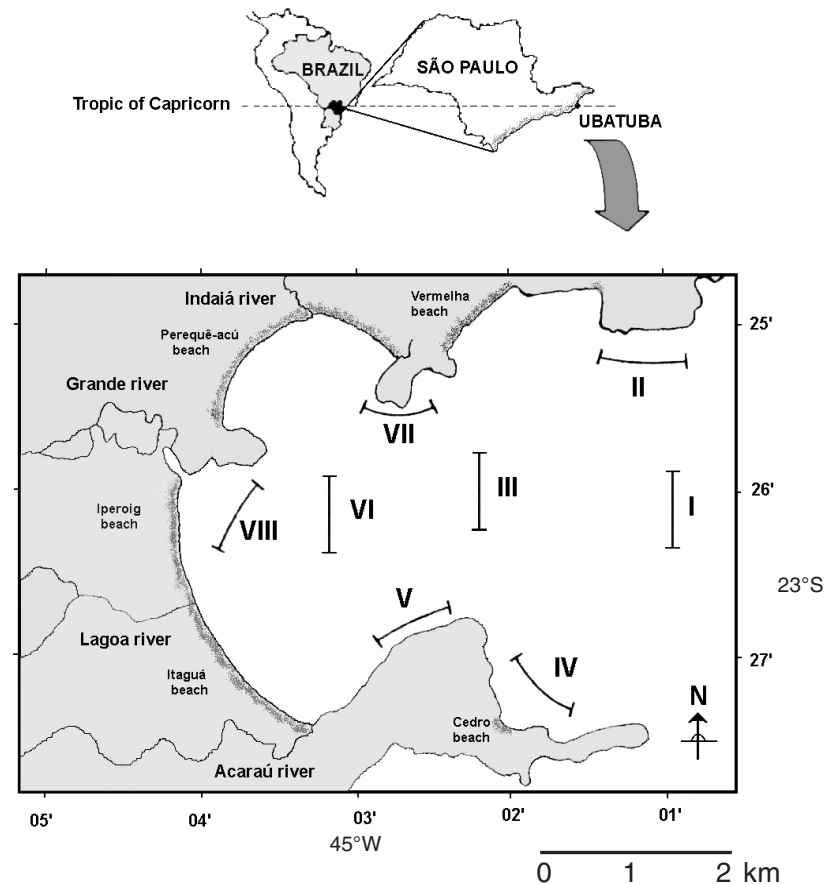

Figure 1. Map of ubatuba bay indicating the locations of the sampling transects.

The specimens are deposited in the collection of the Group of Studies on Crustacean Biology, Ecology and Culture (NEBECC), Department of Zoology, Institute of Biosciences, UNESP, Botucatu, São Paulo, Brazil.

The correlations between the mean numbers of spineshrimps and environmental variables were analyzed employing Pearson's correlation coefficient (VIEIRA 1989). The median sizes of the spine-shrimps were compared by the Kruskal-Wallis analysis, complemented by Dunn's method (SOKAL \& RoHLF 1995) when differences were detected. The significance level adopted for all tests was $\mathrm{p}<0.05$.

\section{RESULTS}

The total number of specimens of E. oplophoroides obtained in this study was 9790 . The number of specimens measured in the subsamples was 2410 . Of the specimens in the subsamples, 1203 were non-ovigerous and 1207 were ovigerous.

Size-frequency distributions were constructed separately for ovigerous shrimps and non-ovigerous shrimps, using 1.5 $\mathrm{mm}$ CL size intervals. The specimens were distributed in ten size classes, ranging from 4.0 to $19.0 \mathrm{~mm}$. The smallest ovigerous shrimp was found in the second size class $(6.3 \mathrm{~mm} \mathrm{CL})$, and the largest in the $10^{\text {th }}(17.6 \mathrm{~mm} \mathrm{CL})$.

Individuals of $E$. oplophoroides occurred on six of the eight transects (I, II, III, IV, VI and VII). Almost all of them were 
Table I. Mean values and standard deviations of the environmental factors on each transect, in Ubatuba Bay from September 1995 to August 1996 (data from Mantelatto \& Fransozo 1999).

\begin{tabular}{cccccc}
\hline Transects & Salinity & Dissolved Oxygen $(\mathrm{g} / \mathrm{ml})$ & Depth $(\mathrm{m})$ & Temperature $\left({ }^{\circ} \mathrm{C}\right)$ & Organic Matter content $(\%)$ \\
\hline I & $33.7 \pm 1.5$ & $4.9 \pm 0.4$ & $16.6 \pm 0,9$ & $22.5 \pm 2.9$ & $5.5 \pm 5.1$ \\
II & $33.3 \pm 1.7$ & $5.2 \pm 0.8$ & $11.4 \pm 0.6$ & $23.4 \pm 2.7$ & $5.3 \pm 3.0$ \\
III & $33.4 \pm 1.7$ & $4.6 \pm 0.8$ & $10.7 \pm 0.7$ & $23.4 \pm 2.8$ & $13.2 \pm 1.5$ \\
IV & $33.2 \pm 1.8$ & $5.2 \pm 0.4$ & $9.5 \pm 1.0$ & $23.7 \pm 2.8$ & $18.5 \pm 9.6$ \\
V & $33.1 \pm 2.0$ & $5.5 \pm 0.5$ & $7.9 \pm 1.1$ & $23.9 \pm 2.6$ & $20.3 \pm 6.6$ \\
VI & $33.1 \pm 1.8$ & $5.2 \pm 0.6$ & $7.6 \pm 0.5$ & $24.0 \pm 2.6$ & $14.5 \pm 2.2$ \\
VII & $32.9 \pm 1.9$ & $4.8 \pm 0.8$ & $7.3 \pm 0.4$ & $24.1 \pm 2.8$ & $6.1 \pm 2.4$ \\
VIII & $32.4 \pm 2.0$ & $5.4 \pm 0.6$ & $3.1 \pm 0.3$ & $24.9 \pm 2.9$ & $6.9 \pm 1.5$ \\
\hline
\end{tabular}

Table II. Mean values and standard deviations of the environmental factors recorded monthly in Ubatuba Bay from September 1995 to August 1996 (data from Mantelatto \& Fransozo 1999).

\begin{tabular}{lcccc}
\hline \multicolumn{1}{c}{ Months } & Salinity $(\%)$ & Dissolved Oxygen $(\mathrm{g} / \mathrm{ml})$ & Temperature $\left({ }^{\circ} \mathrm{C}\right)$ & Organic matter content $(\%)$ \\
\hline September & $31.6 \pm 0.6$ & $5.4 \pm 0.7$ & $22.4 \pm 0.5$ & $13.7 \pm 8.6$ \\
October & $32.7 \pm 0.4$ & $5.0 \pm 0.6$ & $22.4 \pm 0.4$ & $17.0 \pm 8.4$ \\
November & $29.6 \pm 0.9$ & $5.1 \pm 0.9$ & $23.5 \pm 0.8$ & $12.9 \pm 10.1$ \\
December & $31.5 \pm 0.5$ & $5.5 \pm 0.5$ & $22.2 \pm 2.8$ & $10.6 \pm 7.6$ \\
January & $35.3 \pm 0.4$ & $4.7 \pm 0.7$ & $26.6 \pm 0.5$ & $11.3 \pm 8.2$ \\
February & $31.8 \pm 0.9$ & $4.7 \pm 0.6$ & $27.9 \pm 0.9$ & $11.9 \pm 8.3$ \\
March & $34.5 \pm 0.4$ & $5.9 \pm 0.7$ & $27.4 \pm 1.1$ & $8.9 \pm 6.5$ \\
April & $35.2 \pm 0.3$ & $4.7 \pm 0.5$ & $26.0 \pm 0.3$ & $11.0 \pm 8.4$ \\
May & $32.7 \pm 1.0$ & $5.3 \pm 0.5$ & $23.5 \pm 0.9$ & $10.0 \pm 6.8$ \\
June & $34.4 \pm 0.2$ & $4.3 \pm 0.5$ & $23.1 \pm 0.2$ & $9.3 \pm 3.3$ \\
July & $34.6 \pm 0.6$ & $5.0 \pm 0.4$ & $20.2 \pm 0.3$ & $10.8 \pm 5.3$ \\
August & $34.2 \pm 0.5$ & $5.5 \pm 0.2$ & $19.6 \pm 0.3$ & $10.1 \pm 6.7$ \\
\hline
\end{tabular}

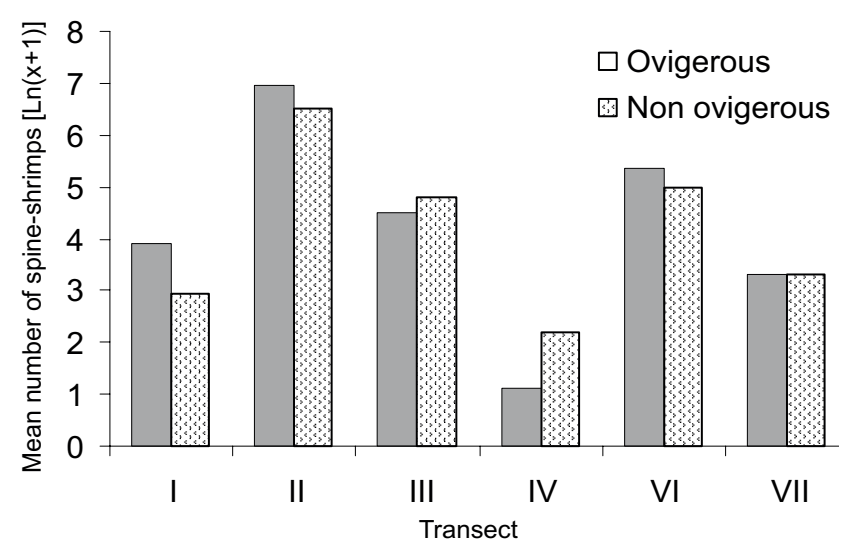

Figure 2. Abundance of ovigerous and non-ovigerous spine-shrimps E. oplophoroides at the collecting sites in Ubatuba Bay.

caught on transect II (Fig. 2). Most of the shrimps were caught in late spring and throughout the summer, from November 1995 to March 1996.
The size (CL) frequency distribution of the shrimps on each transect is presented in figure 3. On each transect, the proportions of ovigerous and non-ovigerous shrimps were similar. There was a statistically significant difference (KruskalWallis, $\mathrm{p}<0.05)$ in the median size of shrimps from different sites (Tab. III).

The size (CL) frequency distributions of the shrimps in each month are shown in figure 4 . The proportion between ovigerous and non-ovigerous shrimps was very similar throughout the year. The population was unimodal. Juveniles were considered as those individuals, which were smaller than the smallest ovigerous females. They were most abundant in December 1995 and in February, April and May 1996.

Among the environmental factors analyzed, only the water temperature (Pearson's coefficient $=0.26$ ) and the organic matter content of the sediment (Pearson's coefficient = 0.27 ) showed a significant correlation with the mean number of spine-shrimps throughout the study period (Fig. 5). However, less than $30 \%$ of the occurrence of the spine-shrimps can be explained by means of these factors. 

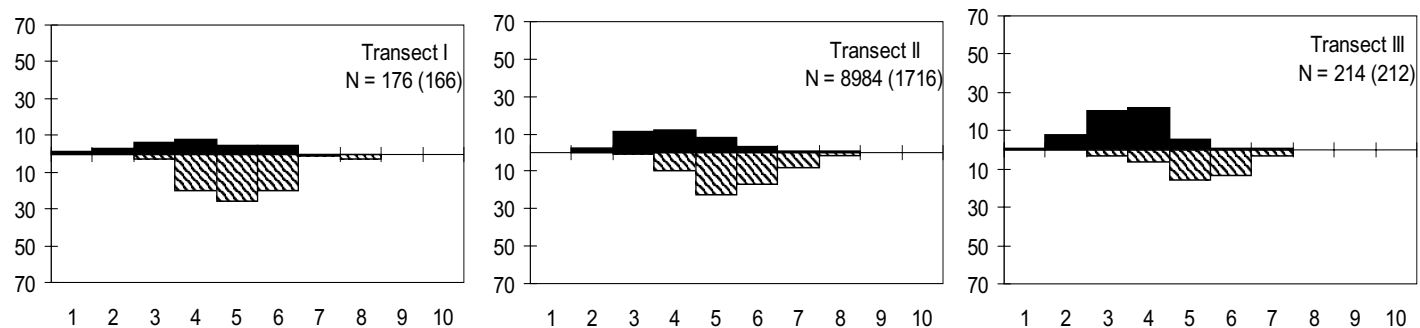

\begin{tabular}{cc}
\hline Size classes & Range $(\mathrm{mm})$ \\
\hline 1 & $4.0-] 5.5$ \\
2 & $5.5-] 7.0$ \\
3 & $7.0-] 8.5$ \\
4 & $8.5-] 10.0$ \\
5 & $10.0-] 11.5$ \\
6 & $11.5-] 13.0$
\end{tabular}
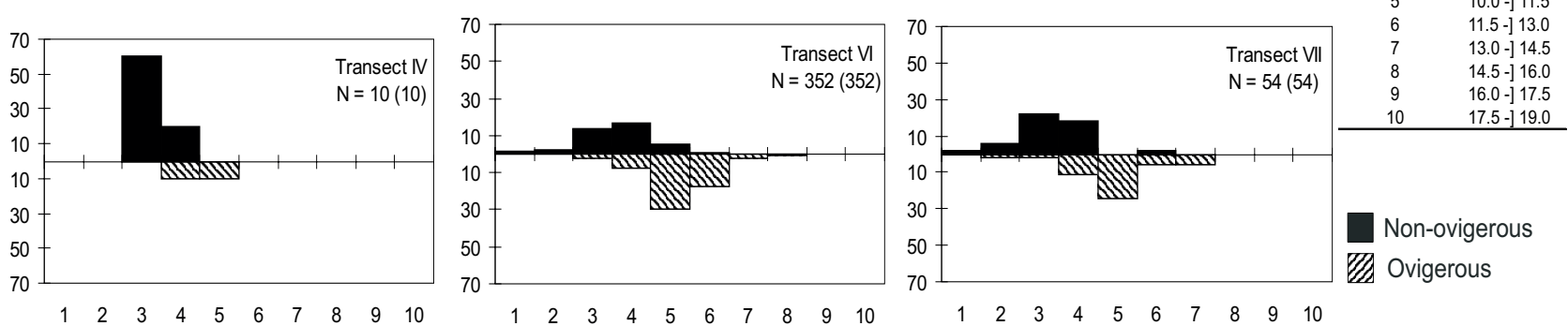

Figure 3. Size-frequency distribution of ovigerous and non-ovigerous spine-shrimps $E$. oplophoroides, at the collecting sites (transects) in Ubatuba Bay, from September 1995 to August 1996. (N) Total number, (n) subsample.

Table III. Exhippolysmata oplophoroides. Comparison of the median size of the spine-shrimps collected.

\begin{tabular}{lrcc}
\hline Season/Sites & $\mathrm{N}$ & Median Size $(\mathrm{mm})$ & Statistical comparison* \\
\hline Winter & 258 & 11.6 & $\mathrm{a}^{\star *}$ \\
Autumn & 470 & 10.5 & $\mathrm{~b}$ \\
Spring & 833 & 10.4 & $\mathrm{C}$ \\
Summer & 849 & 9.7 & $\mathrm{C}$ \\
II & 1716 & 10.5 & $\mathrm{a}$ \\
I & 166 & 10.3 & $\mathrm{ab}$ \\
VI & 352 & 10.0 & $\mathrm{bc}$ \\
VII & 54 & 9.2 & $\mathrm{C}$ \\
III & 212 & 9.1 & $\mathrm{C}$ \\
IV & 10 & 8.0 & $\mathrm{C}$ \\
\hline
\end{tabular}

* Kruskal-Wallis analysis complemented by Dunn's method; $\alpha=$ $0.05 ; * *$ Seasons or sites sharing at least one letter in the column did not differ statistically.

\section{DISCUSSION}

According to CASTRO-FilHo et al. (1987), the region is strongly influenced by three water masses: South Atlantic Central Water (SACW) with low temperature and salinity $\left(\mathrm{T}<20^{\circ} \mathrm{C}\right.$, $\mathrm{S}<36$ ), Tropical Water (TW) with high temperature and salinity $\left(\mathrm{T}>20^{\circ} \mathrm{C}, \mathrm{S}>36\right)$, and Coastal Water $(\mathrm{CW})$ with high temperature and low salinity $\left(\mathrm{T}>20^{\circ} \mathrm{C}, \mathrm{S}<36\right)$. These water masses interact to modify the temperature, salinity and nourishment conditions during the seasons, especially during winter and late spring or summer. According to PIREs (1992), CW and SACW interact, forming a mixing zone that varies in time and space according to the penetration intensity of the SACW. The SACW mass strongly influences the near-bottom sea temperature, especially on the inner shelf during the spring or summer.

The intrusion of SACW was detected in this study during late spring at the $17-\mathrm{m}$ isobath, i.e., on transect I. Our results indicate that fluctuations in the seasonal distribution of $E$. oplophoroides were influenced by the variation in temperature levels caused by these currents. When SACW reaches the bay, it causes a decrease in temperature and confinement of the shrimp population in shallower areas $(<20 \mathrm{~m})$. Similar results were also reported for the shrimp X. kroyeri by NAKAGAKI \& Negreiros-Fransozo (1998) and Castro et al. (2005), Rimapenaeus constrictus (Stimpson, 1874) by Costa \& Fransozo (2004b), the "Argentinean" shrimp Pleoticus muelleri Bate, 1888 by Costa et al. (2004) and the rock-shrimp Sicyonia dorsalis Kingsley, 1878 by Costa et al. (2005b), all in Ubatuba Bay.

The highest abundance of E. oplophoroides occurred on transects II and VI. Abundance is not determined only by a specific group of abiotic factors, but also depends on a group of biotic factors. These transects contained large deposits of plant debris derived from the neighboring terrestrial vegetation (Mantelatto \& Fransozo 1999). According to Castro et al. (2005), these features are essential for the establishment of juvenile shrimps of $X$. kroyeri. The organic material can provide a sheltered environment that allows the establishment and maintenance of the spine-shrimp population, especially for the ovigerous females.

With reference to the size range of the shrimps, the single possible comparison is with the data of Chacur \& NegreirosFransozo (1999), who found a size range from 6.2 to $16.6 \mathrm{~mm}$ CL for the total population, with ovigerous shrimps varying from 7.2 to $15.7 \mathrm{~mm} \mathrm{CL}$. In the present study, the specimens 

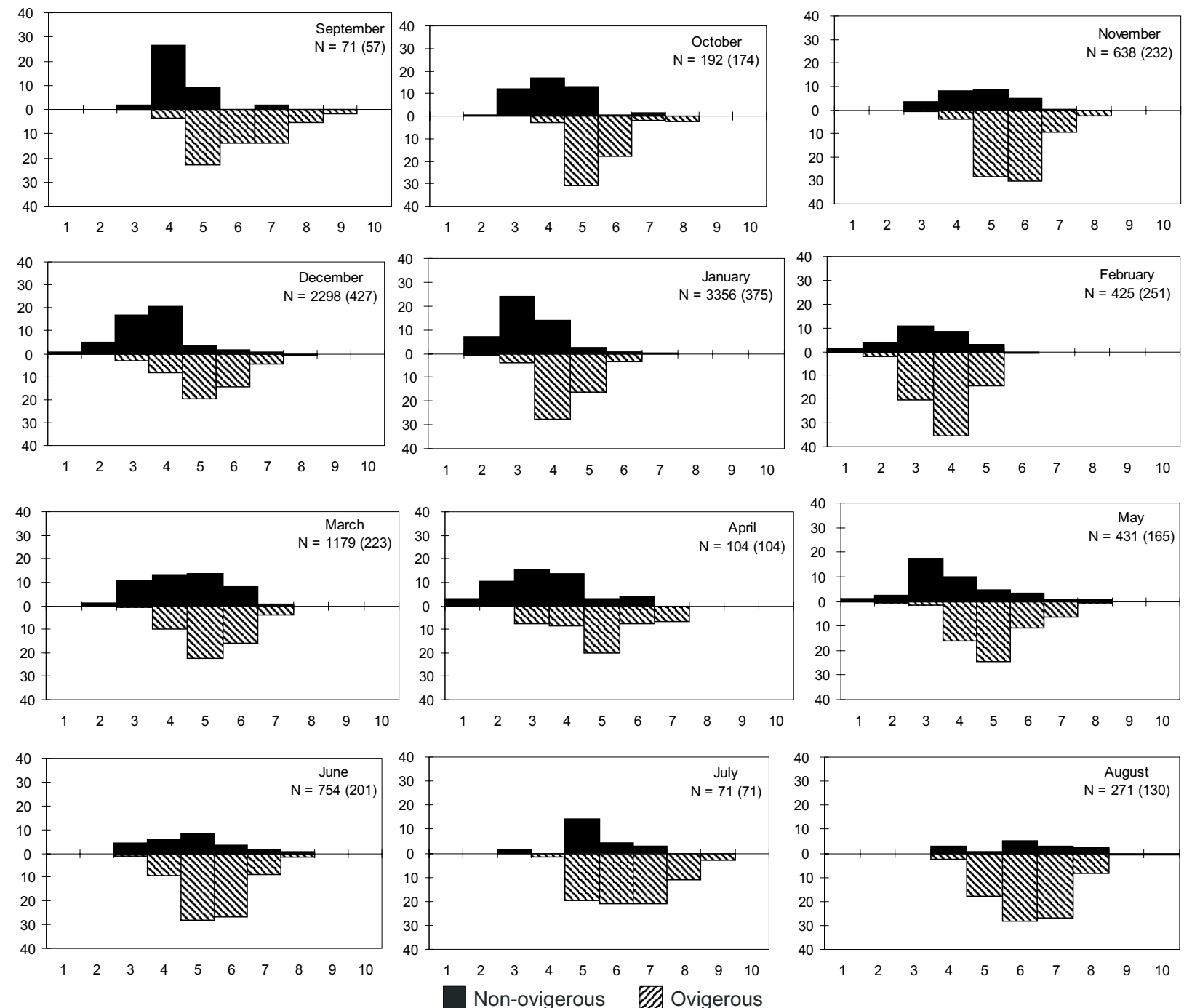

Figure 4. Size-frequency distribution of ovigerous and non-ovigerous spine-shrimps E. oplophoroides, in the months of collection in Ubatuba Bay. (N) Total number, (n) subsample.

measured from 4.1 to $17.6 \mathrm{~mm} \mathrm{CL}$ for the total population, and ovigerous shrimps varied from 6.3 to $17.6 \mathrm{~mm}$ CL. Therefore, we found a slightly wider size variation than in the previous study, perhaps because of a more appropriate sampling design.

According to SASTRY (1983), there is much inter- and intraspecific variation in spawning patterns, depending on the geographic area. Usually, populations in temperate waters spawn over a short period of time compared to those in subtropical and tropical areas. In the tropics, the great majority of the species breed for a long period of time, but peaks may occur within this period. The spine-shrimp showed continuous reproduction in the Ubatuba region: ovigerous females were found year-round, in spite of being more frequent during win- ter. Similar results were found by Costa \& Fransozo (2004b) for the peneid $R$. constrictus in the same region, and by GALVÃo \& Bueno (1999) and Mossolin \& BuEno (2002) for the carideans Atya scabra (Leach, 1815) and Macrobrachium olfersi (Wiegmann, 1836), respectively, from the Municipality of São Sebastião, which is located near Ubatuba Bay at the same latitude. The most frequent breeding period was late spring and summer.

Other decapod species from the same region, such as Paguristes tortugae Schmitt, 1933, studied by Negreiros-Fransozo \& Fransozo (1992), show continuous reproduction throughout the year. Fransozo \& MANTElatTo (1998) observed that another decapod species, Calcinus tibicen (Herbst, 1791), shows a strong reproductive peak between September and May, with ovigerous females absent during the winter months. The reproduc- 

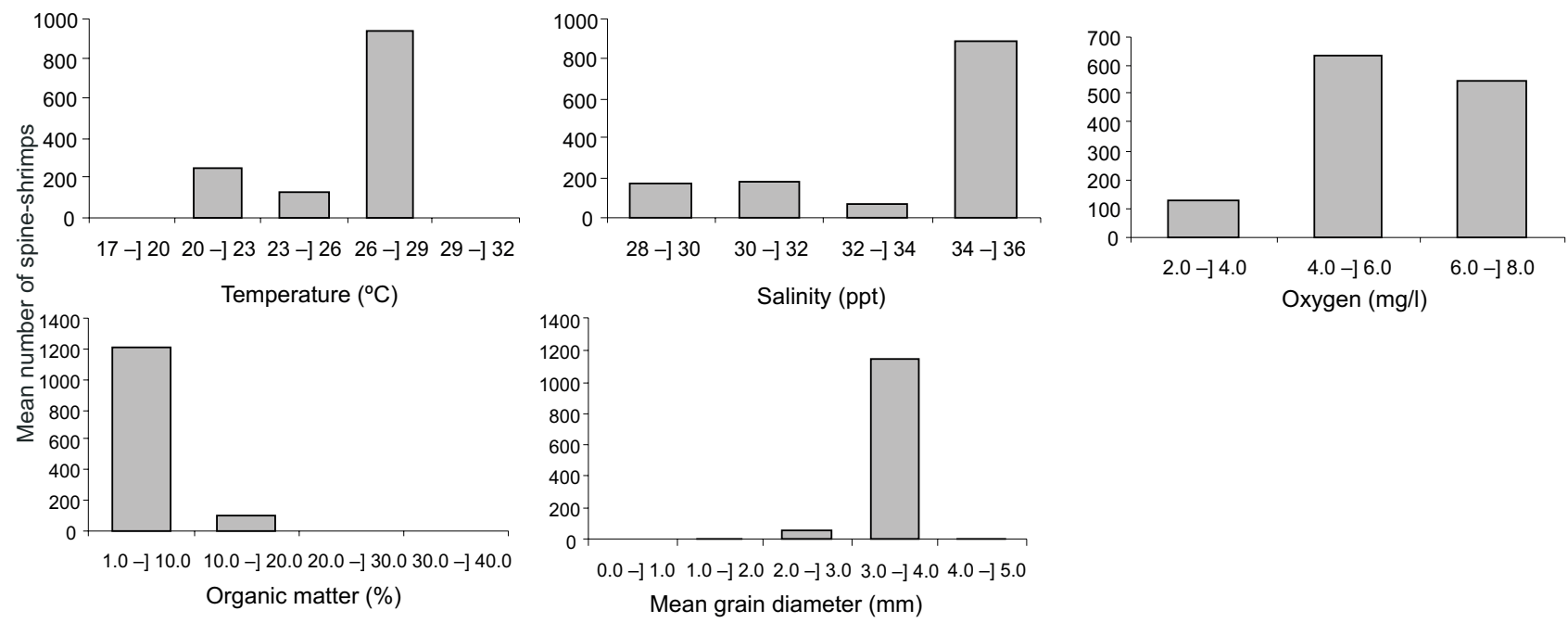

Figure 5. Mean number of spine-shrimps E. oplophoroides, in the entire sample taken in Ubatuba Bay, by class of environmental factor analyzed (salinity, organic matter content, oxygen, temperature and grain size).

tive cycles of decapods can vary from place to place and among species, suggesting that several factors can influence their reproductive process. Because many other aspects of the biology of E. oplophoroides remain poorly known (reproduction, life cycle, ecology, etc), other studies should be developed to improve our knowledge of this species and its life history.

Acknowledgments

To FAPESP for financing part of the field trips (\#94/48788), and to NEBECC students Bianka Noronha and Ricardo Figueira for their help during the sampling and laboratory work. To Dr. Janet Reid for her constructive comments on early drafts of the manuscript and great help with English language. All sampling done in this study complies with current applicable state and federal laws.

\section{REFERENCES}

BAUER, R.T. 1986. Sex change and life history pattern in the shrimp Thor manningi (Decapoda: Caridea): a novel case of partial protandric hermaphroditism. Biological Bulletin, Woods Hole, 170: 11-31.

BAUER, R.T. \& R.T. HolT. 1998. Simultaneous hermaphroditism in the marine shrimp Lysmata wurdemanni (Caridea: Hippolytidae): an undescribed sexual system in the decapod Crustacea. Marine Biology, Berlin, 132: 223-235.

Bertini, G. \& A. Fransozo. 1999. Spatial and seasonal distribution of Petrochirus diogenes (Anomura, Diogenidae) in the Ubatuba bay, São Paulo, Brazil. Iheringia Sér. Zool., Porto Alegre, (86): 145-150.

Buchanan, B.A. \& A.W. SToner. 1988. Distributional patterns of blue crabs (Callinectes spp.) in a tropical estuarine lagoon. Estuaries, University, Mississippi, 11 (4): 231-239.

Castro, R.H.; R.C. Costa; A. Fransozo \& F.L.M. Mantelatto. 2005.
Population structure of the seabob shrimp Xiphopenaeus kroyeri (Heller, 1862) (Crustacea, Penaeoidea) in the littoral of São Paulo, Brazil. Scientia Marina, Barcelona, 69 (1): 105112.

Castro-Filho, B.M.; L.B. Miranda \& Y. Myao. 1987. Condições hidrográficas na plataforma continental ao largo de Ubatuba: variações sazonais e em média escala. Boletim do Instituto Oceanográfico, São Paulo, 35 (2): 135-151.

Chacur, M.M. \& M.L. Negreiros-Fransozo. 1999. Aspectos biológicos do camarão-espinho Exhippolysmata oplophoroides (Holthuis, 1948) (Crustacea, Caridea, Hippolytidae). Revista Brasileira de Biologia, São Carlos, 59 (1): 173-181.

Costa, R.C. \& A. Fransozo. 2004a. Abundance and ecologic distribution of the shrimp Rimapenaeus constrictus (Crustacea: Penaeidae) in the northern coast of São Paulo State, Brazil. Journal of Natural History, Oxfordshire, 38 (7): 901-912.

Costa, R.C. \& A. Fransozo. 2004b. Reproductive biology of the shrimp Rimapenaeus constrictus (Stimpson, 1874) (Crustacea, Decapoda, Penaeidae) in Ubatuba region, SP, Brazil. Journal of Crustacean Biology, Lawrence, 24 (2): 274-281.

Costa, R.C.; A. Fransozo; F.L.M. Mantelatto \& R.H. Castro. 2000. Occurrence of shrimp species (Crustacea: Decapoda: Natantia: Penaeidea and Caridea) in Ubatuba Bay, Ubatuba, SP, Brazil. Proceedings of the Biological Society of Washington, Lawrence, 113 (3): 776-781.

Costa, R.C.; A. Fransozo \& A.P. Pinheiro. 2004. Ecological distribution of the shrimp Pleoticus muelleri (Bate, 1888) (Decapoda: Penaeoidea) of Southeastern Brazil. Hydrobiologia, Dordrecht, 529: 195-203.

Costa, R.C.; A. Fransozo; A.L. Castilho \& F.A.M. Freire. 2005 a. Annual, seasonal and spatial variation of abundance of the 
shrimp Artemesia longinaris (Decapoda: Penaeoidea) in southeastern Brazil. Journal of the Marine Biological Association of the United Kingdom, Plymouth, UK, 85: 107-112.

Costa, R.C.; A. Fransozo \& M.L. Negreiros-Fransozo. 2005b. Ecology of the rock shrimp Sicyonia dorsalis Kingsley, 1878 (Crustacea: Sicyoniidae) in a subtropical region of Brazil. Gulf and Caribbean Research, Ocean Springs, 17 (1).

FiedLer, G.C. 1998. Functional, simultaneous hermaphroditism in female-phase Lysmata amboinensis (Decapoda: Caridea: Hippolytidae). Pacific Science, Honolulu, 52 (2): 161-169.

Fransozo, A. \& F.L.M. Mantelatto. 1998. Population structure and reproductive period of the tropical hermit crab Calcinus tibicen (Decapoda, Diogenidae) in the Ubatuba region, São Paulo, Brazil. Journal of Crustacean Biology, Lawrence, 18: 446-452.

Galvão, R. \& S.L.S. Bueno. 1999. Population structure and reproductive biology of the camacuto shrimp, Atya scabra (Decapoda: Caridea. Atyidae) from São Sebastião, Brazil, p. 291-299. In: J.C.V. Vaupel Klein \& F.R. Schram (Eds). The biodiversity crisis and Crustacea. Rotterdam, A.A. Balkema, Brookfield, Crustacean Issues, vol. 12, 848p.

González-Gurriarán, E.; J. Freire \& L. Fernández. 1993. Geostatistical analysis of spatial distribution of Liocarcinus depurator, Macropipus tuberculatus and Polybius henslowii (Crustacea: Brachyura) over the Galician continental Shelf (N.W. Spain). Marine Biology, Berlin, 115: 115-461.

Kagwade, P.V. 1981. Hermaphrodite prawn Exhippolysmata ensirostris Kemp. Indian Journal of Fisheries, Chennai, 28: 189-194.

Mantelatto, F.L.M. \& A. Fransozo. 1999. Characterization of the physical and chemical parameters of Ubatuba Bay, northern coast of São Paulo State, Brazil. Revista Brasileira de Biologia, São Carlos, 59 (1): 23-31.

Received in 07.III.2005; accepted in 10.XI.2005.
Mossolin, E.C. \& S.L.S. BuENo. 2002. Reproductive biology of Macrobrachium olfersii (Decapoda: Palaemonidae) in São Sebastião, Brazil. Journal of Crustacean Biology, Lawrence, 22 (2): 367-376.

NakagaKi, J.M. \& M.L. Negreiros-Fransozo. 1998. Population biology of Xiphopenaeus kroyeri (Heller, 1862) (Decapoda: Penaeidae) from Ubatuba Bay, São Paulo Brazil. Journal of Shellfish Research, Hanover, 17 (4): 931-935.

Negreiros-Fransozo, M.L. \& A. Fransozo. 1992. Estrutura populacional e determinação do tamanho da concha em Paguristes tortugae Schmitt, 1933 (Crustacea, Decapoda, Anomura) do litoral paulista. Biotemas, Florianópolis, 4 (2): 135-148.

Negreiros-Fransozo, M.L.; J.I. González-Gordillo \& A. Fransozo. 2002. First larval stage of Exhippolysmata oplophoroides (Holthuis, 1948) (Decapoda, Caridea, Hippolytidae) obtained in laboratory. Nauplius, Botucatu, 10 (1): 67-71.

Pires, A.M.S. 1992. Structure and dynamics of benthic megafauna on the continental shelf offshore of Ubatuba, Southeastern Brazil. Marine Ecology Progress Series, Luhe, Germany, 86: 63-76.

SASTRY, A.N. 1983. Ecological aspects of reproduction, p. 179270. In: F.O.J. Vernberg \& N.B. Vernberg (Eds). Biology of Crustacea 8: environmental adaptations. New York, Academic Press, 383p.

SOKAL, R.R. \& F.J. Rohlf. 1995. Biometry. New York, W.H. Freeman, $3^{\text {rd }}$ ed., $887 p$.

VIEIRA, S. 1989. Introdução à bioestatística. Rio de Janeiro, Campus, 293p.

Wenner, E.L.; W.P. Conn III \& M.H. Shealy. 1991. A comparison of species composition and abundance of decapod crustaceans and fishes from the North and South Edisto rivers in South Carolina. South Carolina Marine Research Center, Technical Report, Charleston, 78: 1-48. 